\title{
Regional and latitudinal patterns of soft-bottom macrobenthic invertebrates along French coasts: Results from the RESOMAR database
}

Gallon Régis K. 1, 2, ", Lavesque Nicolas ${ }^{4}$, Grall Jacques ${ }^{2,3}$, Labrune Céline ${ }^{4}$, Gremare Antoine ${ }^{5}$, Bachelet Guy ${ }^{4}$, Blanchet Hugues ${ }^{4}$, Bouchet Vincent M.P. ${ }^{6}$, Dauvin Jean-Claude ${ }^{7}$, Desroy Nicolas ${ }^{8}$, Gentil Franck $^{9}$, Guerin Laurent ${ }^{10}$, Houbin Céline ${ }^{9}$, Jourde Jérôme ${ }^{11}$, Laurand Sandrine ${ }^{3}$, Le Duff Michel $^{3}$, Le Garrec Vincent ${ }^{3}$, De Montaudouin Xavier ${ }^{4}$, Olivier Frédéric ${ }^{12}$, Orvain Francis ${ }^{13}$, Sauriau Pierre-Guy ${ }^{11}$, Thiebaut Éric ${ }^{9}$, Gauthier Olivier ${ }^{2,3}$

${ }^{1}$ Conservatoire National des Arts et Métiers/INTECHMER - Laboratoire Universitaire des Sciences Appliquées de Cherbourg LUSAC, UNICAEN, 51000 Cherbourg, France

2 Institut Universitaire Européen de la Mer, UMR CNRS/UBO/IRD/IFREMER 6539, LEMAR, Place Nicolas Copernic, 29280 Plouzané, France

${ }^{3}$ Université de Brest, CNRS, UMS 3113, Observatoire, Séries Faune-Flore, OSU-IUEM, Rue Dumont d'Urville, 29280 Plouzané, France

${ }^{4}$ Université de Bordeaux, CNRS, UMR 5805, EPOC, Station Marine d'Arcachon, 2 Rue du Professeur Jolyet, 33120 Arcachon, France

${ }^{5}$ Sorbonne Universités, UPMC Univ Paris 6, UMR CNRS/UPMC 8222, LECOB, Observatoire Océanologique, 66650 Banyuls/Mer, France

${ }^{6}$ Université de Lille, CNRS, Univ. Littoral Côte d'Opale, UMR 8187, LOG, Laboratoire d'Océanologie et de Géosciences, F 62930 Wimereux, France

${ }^{7}$ Université de Normandie, UNICAEN, Laboratoire Morphodynamique Continentale et Côtière, UMR

6143 M2C, 24 rue des Tilleuls, 14000 Caen, France

${ }^{8}$ LER Bretagne Nord, IFREMER, 38 rue du Port Blanc, 35801 Dinard, France

${ }^{9}$ Sorbonne Universités, UPMC Univ Paris 6, CNRS, Station Biologique de Roscoff, Adaptation et

Diversité en Milieu Marin, UMR 7144, Place Georges Teissier, 29680 Roscoff, France

${ }^{10}$ Service des Stations Marines, Muséum National d'Histoire Naturelle, Station Marine de Dinard -

CRESCO, 38 rue du Port Blanc, 35801 Dinard, France

${ }_{11}$ Université La Rochelle, UMR CNRS/7266, LIENSs, Bâtiment ILE, 2 rue Olympe de Gouges, 17000

La Rochelle, France

${ }_{12}$ Muséum National d'Histoire Naturelle, Station Marine de Concarneau, UMR

CNRS/MNHN/UPMC/UCBN/IRD 7208, BOREA, Esplanade de la Paix, 14032 Caen cedex, France

${ }_{13}$ Université de Normandie, UNICAEN, UMR CNRS/MNHN/UPMC/UCBN/IRD 7208, BOREA, Esplanade de la Paix, 14032 Caen cedex, France

* Corresponding author : Régis K. Gallon, email address : regis.gallon@lecnam.net

\begin{abstract}
:
This study aims to describe the patterns of soft bottom macrozoobenthic richness along French coasts. It is based on a collaborative database developed by the "Réseau des Stations et Observatoires Marins"
\end{abstract}


(RESOMAR). We investigated patterns of species richness in sublittoral soft bottom habitats (EUNIS level 3) at two different spatial scales: 1) seaboards: English Channel, Bay of Biscay and Mediterranean Sea and 2) $0.5^{\circ}$ latitudinal and longitudinal grid. Total observed richness, rarefaction curves and three incidence-based richness estimators (Chao2, ICE and Jacknife1) were used to compare soft bottom habitats species richness in each seaboard. Overall, the Mediterranean Sea has the highest richness and despite higher sampling effort, the English Channel hosts the lowest number of species. The distribution of species occurrence within and between seaboards was assessed for each major phylum using constrained rarefaction curves. The Mediterranean Sea hosts the highest number of exclusive species. In pairwise comparisons, it also shares a lower proportion of taxa with the Bay of Biscay $(34.1 \%)$ or the English Channel (27.6\%) than that shared between these two seaboards (49.7\%). Latitudinal species richness patterns along the Atlantic and English Channel coasts were investigated for each major phylum using partial LOESS regression controlling for sampling effort. This showed the existence of a bell-shaped latitudinal pattern, highlighting Brittany as a hotspot for macrobenthic richness at the confluence of two biogeographic provinces.

\section{Highlights}

- Regional and latitudinal patterns of soft-bottom invertebrates are investigated. Macrobenthic richness differs consistently between the three French seaboards. The Mediterranean Sea is a hotspot for the major phyla studied. Latitudinal pattern along the Atlantic and English Channel coasts show a bell-shaped. Brittany is a hotspot at the confluence of two biogeographic provinces.

Keywords : Zoobenthos, Species richness, Regional pattern, Latitudinal pattern, Soft-bottom, France

\section{Introduction}

Accurately describing contemporary large-scale patterns of marine macrobenthic diversity is one of the major objectives of marine ecological research (Renaud et al., 2009, Vandepitte et al., 2010). It is particularly relevant in the context of climate change as the distribution of some crustaceans (e.g. Pezy and Dauvin, 2016), bivalves (Philippart et al., 2003), gastropods (Mieszkowska et al. 2007) and polycheates (Wethey and Woodin, 2008) are reported to move further North following temperature increase. However benthic species response to increasing temperature seems to be complex (Hawkins et al., 2009) and slow 
(Hinz et al., 2011). Indeed, differences in distribution change rates have been reported among taxa as well as among life traits (see Pinsky et al., 2013, Poloczanska et al., 2013), illustrating differential responses to climate change among marine life compartments (e.g. highly motile vs sligthly motile). Furthermore, global change also includes the introduction of alien species and anthropogenic pressures to coastal ecosystems, which are another major threats for marine biodiversity (Harley et al., 2006, Occhipinti-Ambrogi, 2007) that modifies species composition at the regional scale.

While it is still unclear exactly how global change will modify the regional distribution of species, it seems likely that these changes will occur mostly along latitudinal gradients. In order to track and understand these changes it is necessary to describe and analyze recent and contemporary macrobenthic diversity patterns in this context. Only in doing so can we address the challenge of proposing plausible proximate and historical causes acting at different scales. Furthermore, the assessment of the global distribution of species richness may help to understand differences across region in the context of invasive species propagation (Occhipinti-Ambrogi, 2007). French coastlines offer an interesting case study to address these questions as they cover a large latitudinal gradient including different biogeographical regions from the Northern European seas down to the Lusitanian province.

Species richness is the most elementary, easy to interpret and widely used measure of biodiversity (e.g. Dornelas et al., 2014). It has been shown to follow a - generally unimodal large-scale $\left(>45^{\circ}\right)$ latitudinal gradient for marine benthic invertebrates with a peak in equatorial regions (Chaudhary et al., 2016).

Marine benthic species richness patterns have scarcely been studied simultaneously on the entirety of French seaboards (from $42^{\circ} \mathrm{N}$ to $51^{\circ} \mathrm{N}$ ). Indeed, existing studies either had either limited geographic scope (e.g. eastern English Channel, Foveau et al., 2013; English 
Channel and Bay of Biscay estuaries, Blanchet et al., 2014; Gulf of Lion, Labrune et al., 2008), or focused only on single taxonomic groups (e.g. polychaetes, Dauvin et al., 2006; amphipods, Dauvin and Bellan-Santini, 2004). French coasts are constituted by three seaboards spread over three distinct biogeographical provinces with contrasted hydro-climatic characteristics: i) the English Channel (hereafter EC) including the 60km of the southern part of the North Sea in the cold temperate Northern European seas, ii) the Bay of Biscay (hereafter BB) in the Lusitanian province and iii) the sub-tropical North-West Mediterranean Sea (hereafter MS) (Spalding et al., 2007). These three seaboards harbor a large panel of sedimentary features (Dauvin, 2015 for the EC; Le Loc'h et al., 2008 for the BB; Aloisi et al., 1973 for the MS). On the one hand, local and regional abiotic variables - temperature, salinity, hydrodynamics and sedimentary features - exert strong environmental control on species distributions from the local to the regional scale (Warwick and Uncles, 1980; Roy et al., 2000; Levin et al., 2001; Gray, 2002; Bonsdorff, 2006; McArthur et al., 2010) and should have a strong impact on species richness patterns at these scales. On the other hand, broadscale climatic and hydrodynamics systems should play a role at broader scales (Wien, 1989; Dinter, 2001; McArthur et al., 2010).

The combination of local, regional and broad-scale processes should result in partially overlapping sets of species as well as richness differences among the three seaboards. Furthermore, because of their adjacency we also expect the EC and BB to share more species than either does with the MS. Indeed, the fluid marine environment offers a wide variety of means to disperse from one location to another (Cowen and Sponaugle, 2009) and most benthic invertebrates (70\%) have a larval stage that facilitates to their dispersion. However, hydrological characteristics of marine biogeographical provinces often lead to the creation of frontal structures limiting larval dispersal (Ayata et al., 2010). 
The present study aims to verify the alleged decrease of diversity towards higher latitudes using a large historical database. However, because it includes the transition between the Northern European seas and the Lusitanian province, we also expect the latitudinal pattern along French Atlantic coasts to be more complex than a simple linear model (e.g. Roy et al., 1998; Hummel et al., 2016). Indeed, biogeographic boundaries potentially host high species richness by combining the diversity of the adjoining biogeographic areas and sustaining species not found elsewhere (Kark and van Rensburg, 2006). Therefore, the present's objectives are threefold (1) to compare species richness of soft-bottom communities between the three French seaboards, (2) to investigate species composition and proportions of shared species among these regional species pools and, (3) to examine latitudinal patterns along French Atlantic coasts. This work was conducted using historical and recent data from a macrobenthic fauna database compiled by the French Réseau des Stations et Observatoires Marins (RESOMAR). This national database was set up within the context of contemporary efforts leading to the constitution of similar large global and regional databases compiling marine biodiversity datasets (e.g. OBIS, Macroben, LargeNet).

\section{Materials and methods}

\subsection{RESOMAR database}

The RESOMAR Benthos Database (http://resomar-benthos.epoc.u-bordeaux1.fr/) compiles historical and current benthic macrofauna datasets collected along the metropolitan France seaboards: English Channel, Bay of Biscay and Mediterranean Sea. It currently holds 106 datasets for a total of 9,990 sampling occasions (or station-date dyads) over a 50-year time period (1961-2011) (Fig. 1). In the RESOMAR Benthos Database sampling tools are disparate, however more than $60 \%$ of sampling occasions were sampled by grabs (e.g. Day, 
Eckman, Hamon, Shipeck, Smith McIntyre). Thus we assumed that, at large-scale, the sampling tools effect was outweighed by that for the sampling effort.The systematic nomenclature of the database was checked following the World Register of Marine Species (WoRMS, http://www.marinespecies.org/). An Expert Committee composed of French experts in taxonomy from the EC, BB and MS was formed to solve possible misidentification issues. International experts were also consulted when needed.

Stations were assigned a habitat type (sensu the European Nature Information System classification- EUNIS, http://eunis.eea.europa.eu/, Davies et al., 2001; Galparsoro et al., 2012) using granulometry (when available) and most abundant species. Otherwise, in the absence of granulometric data, habitat type was derived from sedimentary maps (e.g. CARtographie des HAbitats Marins, REseau BENthique). The EUNIS structure is based on three levels of environmental variables (substrate, biological zone, energy) that define a 'habitat envelope'. Concerning marine habitat types, EUNIS constitutes a hierarchical structure up to six levels combining habitats physical attributes and biological communities, with the levels 1 to 4 informing about the abiotic factors. A total of $67.1 \%$ of sampling occasions were assigned to EUNIS level 4, $17.7 \%$ to EUNIS level 5, and $0.8 \%$ to EUNIS level 6. However, $0.1 \%$ could only be assigned to EUNIS level 2 and 1.2\% to EUNIS level 3. For the remaining 13.1\% sampling occasions neither sediment grain size data nor geographical coordinates were available and no habitat type was assigned.

\subsection{Subtidal soft bottom subset}

This study focuses on large-scale species richness patterns in sublittoral sedimentary habitats (A5. EUNIS) because numerous sampling occasions from these habitats are distributed among the three seaboards. The analysis was conducted at EUNIS level 3 as it was 
the best compromise between precision and the number of available sampling occasions ( $86.8 \%$ of the database). To capture the most information on species richness and to control for seasonal variability (e.g. storms, winter mortalities...), we only selected sampling occasions collected between March and October because this period coincides with the recruitment period of most benthic species. We excluded from our analysis stations that were clearly known as being impacted by pollution or other strong human-induced stress and thus consider that pollution does not play an important role when comparing the species lists from the 3 seaboards.

The selected subset contains 4635 (46.4\%) of the 9,990 sampling occasions (Table 1). Sublittoral sand sediments (A5.2: 2,207 sampling occasions) were the most frequent habitat, while sublittoral mud sediments (A5.3: 964 sampling occasions) and sublittoral coarse sediment (A5.1: 759 sampling occasions) were somewhat less frequent. Mixed sediments (A5.4: 463 sampling occasions) were the least abundant. A total of 923 sediment habitats (A5) sampling occasions were not assigned to EUNIS level 3. The distribution of habitat types differed among the three seaboards (Table 1). In the EC, sand sediments (A5.2) were intensively sampled (1,069 of sampling occasions) relative to the other habitats. In the $\mathrm{BB}$, 993 sampling occasions were in A5.2, 680 in A5.1, 700 in A5.3, and 241 in A5.4. In the MS, mud (A5.3; 184 sampling occasions) and sand sediments (A5.2; 145 sampling occasions) were more frequent than other habitats (A5.4: 59 sampling occasions; A5.1: 31 sampling occasions). This discrepancy warrants the use of methods controlling for sampling effort in the analyses described below. Finally, when the identification of specimens was ambiguous, taxa were designated as their parent taxa (e.g. genus), either across the entire database, or for a specific seaboard. 


\subsection{Data analysis}

\subsubsection{Benthic richness across French seaboards}

Species richness estimates for the three seaboards were obtained with: 1) total observed richness, 2) expected richness as obtained from sample-based taxon sampling curves (Gotelli and Colwell, 2001), and, 3) three incidence-based richness estimators ( $\mathrm{ChaO}_{2}$ : Chao, 1987; ICE: Lee and Chao, 1994; Jackknife1: Burnham and Overton, 1978, 1979) adapted to datasets with varying sample sizes and large sample grain size (Brose et al., 2003; Hortal et al., 2006).

The proportions of shared species between regions were estimated using a constrained rarefaction procedure accounting for differences in sampling effort in the three seaboards. For each seaboard and each comparison, two sample-based rarefaction curves were computed: one for species shared with the other seaboard(s) under consideration, and another for species found only in the considered seaboard. These curves are strictly additive: for a given sampling effort the sum of their expected richness gives the expected richness for the seaboard rarefaction curve, i.e. the one computed using all species in the seaboard. In the two seaboards case four rarefaction curves were computed, two for each seaboard. This procedure thus yielded one estimate for each of the two numbers of species found in a single seaboard and two estimates for the number of species shared between the two seaboards. The lowest of the latter was used as the number of shared species and the exceeding species were simply transferred to the seaboard of origin (see appendix 1 for further details and $\mathrm{R}$ code). Proportions of shared species were estimated for the lowest number of sampling occasions across the three seaboards. 


\subsubsection{Macrobenthic richness latitudinal pattern}

The latitudinal richness pattern in BB and EC was studied by first binning samples in $0.5^{\circ} \times 0.5^{\circ}$ cells (ca. $2100 \mathrm{~km}^{2}$ area). Linear models of richness and sampling efforts, as a function of latitude, were first computed to take into account the disparities in sampling effort along French seaboards. The relationship between species richness and latitude from the Northern EC to the Southern BB was then investigated with LOESS regression between the residuals of these two models (Cleveland et al., 1991).

All data analyses were executed with R 3.1.3 (R Core Team, 2015) using the fossil (Vavrek, 2011), iNEXT (Hsieh and Chao, 2016) and vegan (Oksanen et al., 2015) packages; the RESOMAR database was accessed with the RMySQL package (Ooms et al., 2016).

\section{Results}

\subsection{Subtidal soft bottom subset}

The 5,315 sampling occasions in the subset accounted for 2,880,132 (47.8\%) of the $6,021,856$ individuals in the RESOMAR benthos database and contain 2,624 (84.3\%) of the 3,111 taxa: 1,958 taxa identified to the species level within 1126 genera, 471 families, 132 orders, 52 classes and 13 phyla. From this point on, and for clarity's sake, "species" and "species richness" refer to the lowest taxonomic level at which specimens were identified, either species or genus.

No species was ubiquitous (i.e. occurred in all sampling occasions), and $30.7 \%$ were restricted to $1(20.0 \%)$ or $2(10.7 \%)$ sampling occasions. Only 124 species $(6.1 \%)$ were singletons (i.e. represented by a single individual) and $133(6.5 \%)$ doubletons (i.e. represented by two individuals). 
Overall, annelids and arthropods were the most abundant as well as the richest phyla, accounting for $32.5 \%$ and $28.7 \%$, respectively, of the total observed richness. Molluscs followed with $20.7 \%$ and other less abundant phyla made up less than $5.3 \%$ of the total observed richness (Table 2). Annelids occurred in most (91.4\%) sampling occasions, as well as molluscs (76.7\%) and arthropods (73.9\%). Echinoderms occurred in $61.4 \%$ of sampling occasions, but accounted for only $4.8 \%$ of the total observed species richness (Table 2).

All species richness analyses were first conducted using all phyla listed in Table 2. Species richness patterns were then restricted to the four most abundant and frequent phyla: annelids, arthropods, molluscs and echinoderms.

\subsection{Benthic richness across French seaboards}

There was no clear relationship between species richness and sampling intensity at the seaboard scale. This holds whether sampling effort was expressed as the number of sampling occasions or as the total number of individuals. Indeed, at the seaboard scale, observed and extrapolated species richness increased from north (EC) to south (MS) but the number of sampling occasions was higher in the BB $(2,274)$ than in the other seaboards (EC: 1,520 ; MS: 841; Table 1). Moreover, the number of individuals was three times higher in EC $(1,654,849)$ than in BB $(620,577)$ and MS $(604,706$; Table 1) while species richness in MS was about twice that observed in EC for each subset (Table 1).

Also, as noted before, the distribution of sampling occasions across habitat types differed between seaboards (Table 2)._Comparisons of habitat richness among seaboards yielded no consistent ordering considering either observed or extrapolated richness. Within coarse sediments (A5.1; 573 species) and sand sediments (A5.2; 1,040 species), BB hosted the highest observed richness followed by the MS (A5.1: 326 species; A5.2: 655 species) and the EC (A5.1: 281 species; A5.2: 729 species; Table 1). For mud (A5.3) and mixed sediments 
(A5.4), EC was the poorest seaboard (Table 1). However, taking discrepancies in sampling effort into account gave a consistent pattern of ordering. Rarefied richness for the MS was consistently higher across all habitats (Fig. 2).

Using a constrained rarefaction procedure (see details above), the MS stands out with 954 unique species compared with either the EC or BB, while the BB showed 286 (12\%), and the EC only 143 (6\%) exclusive species (Fig. 3). About a quarter of the 2,386 species in the dataset were shared by the three seaboards ( 555 species or $22 \%$ ). In pairwise comparisons, the MS shared more species with $\mathrm{BB}(\approx 35 \%)$ than with EC $(\approx 28 \%)$ regardless of phyla, while BB and EC shared about $50 \%$ of their species (Table 3).

To summarize, the MS was the least sampled but hosted the highest benthic macroinvertebrates species richness and was characterized by a large number of exclusive species. The EC had the lowest species richness but sampling occasions mostly comprised sand sediments. Despite a large number of sampling occasions, the BB had intermediate species richness. These two contiguous seaboards shared about half of their species.

\subsection{Macrobenthic richness latitudinal pattern}

After controlling for sampling effort, maximal species richness along the BB and EC seaboards was found at the confluence of these two seaboards. Indeed, for all taxa combined, annelids, as well as molluscs, LOESS regression produced bell-shaped curves peaking at Brittany (Fig. 4). Total observed species richness at the $0.5^{\circ}$ grid scale ranged from 30 to 804 taxa in Brittany, compared to richness of 42 to 290 species in the rest of EC and 6 to 406 species in the rest of BB (raw data not shown). The 148 species shared (7.9\%; Fig. 3) between these two seaboards (and also absent from the MS) were mostly found along Brittany's coasts and scarcely elsewhere (results not shown). Moreover, grid cells in Brittany hosted more than 
twice as many species as those in the rest of BB and EC for dominant phyla: polychaetes 280, 154, and 133 species for Brittany, BB, and EC respectively; arthropods 257, 138, and 83 species; molluscs 210, 93, and 58 species; and, echinoderms 144, 39, and 15 species.

\section{Discussion}

Investigating species richness patterns of several high-level taxa at broad-scale and regional scale is an innovative aspect of the present paper. General dominance patterns of the major phyla were of the same order of magnitude as those reported in other studies that cover all, or part, of the area under study (Arvanitidis et al., 2002; Ellingsen and Gray, 2002; Le Loc'h et al. 2008; Sokołowski et al., 2012; Foveau et al., 2013). Annelids and arthropods tend to dominate these communities, in terms of abundance, and often species richness (Knox, 1977; Hutchings, 1998; Arvanitidis et al., 2002 for annelids - Dauvin et al., 1994; Prato and Biandolino, 2005; Lourido et al., 2008 for arthropods).

Explanations for observed richness patterns can be sougth at the local-scale, regionalscale and broader across seaboard-scale. Indeed, temperature influences period of reproduction, the number of cohorts and generations per period of reproduction (univoltism, plurivoltism), egg development, the survival of larvae and adults and the capacity of organisms to settle on substrates (Hiscock et al., 2004). Salinity strongly affects richness patterns: Bonsdorff (2006) revealed a decrease of diversity from the South to the North of the Baltic Sea. Along such gradients, marine species diversity decreases with decreasing salinity and conversely for freshwater diversity (Cognetti and Maltagliati, 2000). Hydrodynamic conditions drive the distribution of invertebrates via transport and dispersal of larvae and adults and can have important consequences on population dynamics (Levin et al., 2001). Furthermore, the physical stress resulting from hydrodynamics determines distribution 
patterns of sedimentary bed forms and therefore plays an important role in the distribution of benthic communities (Stride, 1973; Ellingsen and Gray, 2002; Van Hoey et al., 2004; Dauvin, 2015). Indeed, the 3D structure of sediments can provide refuge for numerous species, and heterogeneous sediments with more potential niches can foster higher diversity than homogeneous sediments (Ellingsen and Gray, 2002).

Although France's seaboards have contrasting hydro-climatic conditions, they are all strongly influenced by freshwater inputs - the Seine River in the Eastern part of the EC; the Vilaine, Loire and Gironde rivers in the BB; the Rhone river in the Gulf of Lion - establishing salinity gradients and dispersal barriers between the coast and the open sea (Bourrin and Durrieu de Madron, 2006; Ayata et al., 2011; Dauvin, 2012). They also share similar softbottom habitat types, i.e coarse sediments (A5.1), sand sediments (A5.2), mud (A5.3) and mixed sediments (A5.4, EUNIS 2016, Habitat Classification level 3). Nonetheless, the prevalence and spatial distribution of these habitats differ from one seaboard to the other due to hydro-climatic and topographic features.

\subsection{Benthic richness across French seaboards}

In accordance with our hypothesis, macrobenthic richness differs among French metropolitan seaboards with the MS having the highest exclusive species and total richness regardless of phyla. At nearly $40 \%$, the proportion of exclusive species is twice the endemism rate reported by Bazairi et al. (2010), but this is certainly an artifact of the more restricted geographic scope of the present study. Still, its complex geological history and higher temperature, are probably responsible for the distinctness of the MS (Coll et al., 2010). The alternation of ice ages and warm interglacial during the Quaternary and the post-Pliocene "diversity pump" from the Atlantic are recognized to have promoted speciation processes in the MS (see Bianchi and Morri, 2000). Also, the MS subset is probably influenced by the 
influx of the NE Atlantic, inducing a wide range of physical and chemical conditions (Pérès, 1967; Coll et al. 2010; Dauvin et al., 2013), which may favor the settlement of both cold and warm water species (Koukouras et al., 2001). Finally, for the past thirty years, several new species have been brought to the MS by way of shipping, aquarium species propagation, and aquaculture (Coll et al., 2010; Nunes et al., 2014).

Because of its complex mosaic of habitats (Le Loc'h et al., 2008) the BB has the potential to host high species richness. Indeed, BB's "Grande Vasière" contributes to the region overall intermediate richness. Large inputs of freshwater that induce large amplitudes of physical and chemical conditions could also favor richness in the region as they allow for the settlement of both cold and warm water species as well as species adapted to brackish waters. The low proportion of species shared between BB and MS could also be an artifact of the RESOMAR database not covering Portuguese and Spanish coasts. Indeed, some holobenthic species originally described as endemic to the MS have been encountered along the Portuguese coast and in the BB which shows deep outputs of saltier waters that spread along the Atlantic coast to the south of Ireland (Dauvin, com. pers.).

In the present study, EC is the most species poor seaboards, with total richness lower than that previously reported for a similar sampling effort (i.e.318 stations in Foveau et al., 2013, Fig. 2). However, this previous study willingly maximized richness by sampling a plethora of coastal and offshore habitats while the present effort is based strictly on coastal monitoring datasets and a restricted set of habitats: for example, the pebble and gravel habitats was the richest of those in Foveau et al (2013), but is not considered here as they are scarcely present in the RESOMAR database. Interestingly, we report nearly twice as many species as Fovau et al. (2013) for sand sediments (729 vs. $<400$ species). At first sight the EC's low species richness could be linked to a north-south richness gradient. However, regional 
ecological, geological and evolutionary processes could also explain the low species richness in the EC. Indeed, after the last glacial maximum (15000 BP), the English Channel was still land and was recolonized only very recently and probably through two different paths - the Celtic Seas and the North Sea - as reported for numerous invertebrate species (Jolly et al., 2006). This recent colonization could thus partly explain the low species richness in the south of the North Sea as species are still migrating to this area from glacial refugia (Ellingsen and Gray 2002). Moreover, differences in richness between regions could also be related to within-region habitat distribution. While the $\mathrm{BB}$ offers a rich mosaic of habitats and the MS harbors contrasted habited along a depth gradient, strong physical constraints in the EC lead to large extents of offshore continuous coarse and sandy sediments that dwarf other habitats and confine muddy habitats to bays and estuaries that cover a small part of this region (Dauvin, 2015). This is reflected in our database where sand sediments dominate the EC (79.8\% of sampling occasions) while the proportions of each habitat are nearly balanced in the BB and MS (Table 1). The Liguro-Provencal current - flowing from east to west maintains Rhône River particles on the continental shelf area where they undergo several deposition/resuspension cycles (Durrieu de Madron et al., 2000; Bonifácio et al., 2014). Coarse sediments of the MS are under-represented in the database because they are restricted to the edge of the shelf and are difficult to sample (Table 1).

The BB and EC share more species than BB and MS which can be explained by the fact that BB and EC form a continuum while the MS is separated from both areas by some $2000 \mathrm{~km}$ of coasts, namely spanish and Portuguese coasts, not included in our dataset. This hypothesis is corroborated by Kinlan and Gaines (2003) who estimated that the genetic dispersion distance range of marine invertebrates varies between a few meters and several hundred kilometers $(>500 \mathrm{~km})$. Nevertheless, the Iroise Sea, located between BB and EC, 
hosts thermal and haline structures that can hinder dispersal between the $\mathrm{EC}$ and $\mathrm{BB}$ (Pingree et al., 1982; Boyer et al., 2009; Ayata et al., 2010) and thus potentially limit the number of shared species between the two seaboards. Indeed, the pelagic stages are strongly sensitive to hydrological discontinuities - i.e. where water bodies have different physical and chemical properties - such as thermic and haline fronts (Ayata et al., 2010). In the BB, the water column is mixed by climatic events during the winter period (storms) and it is stratified during summer (Ayata et al., 2010, 2011) inducing barriers. The Strait of Gibraltar separates the MS from the Atlantic and creates strong currents, as well as thermal and haline fronts (Millot, 1999; Cimmaruta et al., 2005) limiting larval propagation. At the western tip of Brittany, the Iroise Sea and water bodies between Le Conquet and Roscoff host thermic and haline frontal structures, and constitute a cold-water enclave that could favour the settlement of stenotherm species strongly impacted by large thermic amplitude especially in the Eastern Channel (Gallon et al., 2014; Dauvin, 2015). In addition to sea temperature increase, global change induces modifications in current and wind circulations, turbulence, and stratification (Harley et al. 2006). At broad-scale, these modifications could strongly affect connectivity patterns (e.g. time retention, currents speed) and thus deeply modify the current distribution of invertebrates between the three French seaboards. Among these changes, it can be expected that the number of species shared between seaboards will increase, mainly through the arrival of southern-species, eurytherm species, and alien species through shipping or other means of long distance transport. However, because of present hydrodynamic features along French coasts, these changes are not expected to be evenly distributed., Indeed western and northwestern Brittany have been identified as the most stable areas for seaweeds (Gallon et al., 2014). In addition, aquaculture (e.g. oysters) induces transports of living organisms and associated species between the MS and the BB/EC seaboards (e.g. Bachelet et al., 1990; 2004; 
Goulletquer et al. 2002). These activities constitute important vector of long distance species introduction between seaboards separated by several thousand kilometres of coastlines and hydrological barriers and, as such, could contribute to further homogeneisation of benthic invertebrate species assemblages among the MS and BB/EC (Olden and Rooney, 2006).

\subsection{Macrobenthic richness latitudinal pattern}

By focusing on a similar latitudinal extent $\left(42^{\circ} \mathrm{N}\right.$ to $\left.51^{\circ} \mathrm{N}\right)$ most studies conducted at large and medium scales revealed either linear relationship between richness and latitude (Crame, 2000; Rex et al., 1993; Roy et al., 1998; Clarke and Lidgard, 2000; Roy et al., 2000) or no relationship (Dauvin et al., 1994). By reviewing 27 published studies and based on the geographic distribution of 65000 species within the Ocean Biogeographic Information System (OBIS), Chaudhary et al. (2016) revealed a bimodal distribution (peaks at $50^{\circ} \mathrm{N}$ to $55^{\circ} \mathrm{N}$ and $20^{\circ} \mathrm{S}$ to $25^{\circ} \mathrm{S}$ ) that dips close to the equator. Most authors suggest that latitudinal gradients differ both between hemispheres (Crame, 2000; Macpherson, 2002) and marine taxa (Chaudhary et al., 2016). The different hydro-climatic conditions in both hemispheres could explain the geographic asymmetry (e.g. upwelling, rivers; Roy et al., 1998; Macpherson 2002). Nonetheless, an analysis of data published from 1993 and 2003, taking account three major oceans (Pacific, Atlantic, and Indian), did not reveal any pattern differences between northern and southern hemispheres regarding either the slope or the strength of the richness gradient (Hillebrand, 2004). Overall, observed richness tends to decrease with increasing latitude such gradient being supported by data on molluscs (Rex et al., 1993; Roy et al., 1998, 2000; Crame 2000), crustaceans (Dworschak, 2000) as well as bryozoans (Clarke and Lidgard, 2000). In addition, spatial scales of observation can have a great bearing on richness trends and patterns, as well as in the underlying factors governing them (Wiens, 1989; Dinter, 2001; Willig et al., 2003; Hillebrand 2004). Indeed, at medium 
$\left(<10^{\circ}\right)$ and regional spatial scales $\left(<3^{\circ}\right)$, the existence of latitudinal gradients remains controversial as some authors have failed to detect any consistent patterns (Ellingsen and Gray, 2002). Some even reporting opposite trends -i.e. an increase of species richness with higher latitude (e.g. in the North Sea, Heip et al., 1992; Rees et al., 1999; along the Argentina coasts, Doti et al., 2014) or a bell-shaped trend (Gray, 2000; Hummel et al., 2016). Our study revealed a more complex pattern: a bell-shaped curve peaking in Brittany between $47^{\circ} \mathrm{N}$ to $49^{\circ} \mathrm{N}$ latitude (Figure 4). This suggests that local hydroclimatic conditions could be key factors contributing to richness patterns at such a regional scale. Although Brittany was previously recognized as a hotspot for seaweed species biodiversity (Kerswell, 2006; Santelices, et al. 2009) specifically because it is located in a biogeographic transition area, this study gives the first indications that Brittany as a whole, is a hotspot for benthic macrofauna biodiversity. Previous studies had focused on either southern or northern Brittany independently from one another (e.g. Glémarec, 1969; Cabioch et al., 1977) while this is the first study investigating the distribution of macrozoobenthic richness along the entire Atlantic and Channel coasts.

The causes for this pattern may be found in the topographic, hydrodynamic and oceanographic features of the area. Firstly, in Brittany, several coastal embayments (semienclosed areas) are characterized by a mosaic of benthic habitats created by the co-occurrence of fine sediments brought by coastal rivers and coarse sediments originating from strong tidal currents, e.g. the Normano-Breton Gulf (Retière, 1979; Cabral et al., 2015), the Bay of Morlaix (Ehrhold et al., 2011), the Bay of Brest (Grall and Glémarec, 1997), the Bay of Concarneau (Ehrhold et al., 2006) and the gulf of Morbihan (Glémarec, 1964). The heterogeneity of habitats and the co-existence of numerous microhabitats could provide a high number of potential niches and diverse ways to exploit the environmental resources, thus 
increasing species richness (Benedetti-Cecchi and Cinelli, 1995). Surrounding areas such as the eastern part of the EC and the central part of the $\mathrm{BB}$ are highly dominated by large and homogenous habitats (coarse sediments or fine sand) (Chassé et al., 1978; Cabioch, 1968 for the Western Channel). Secondly, the coexistence of sedimentary habitats with rocky habitats at small scales $(\mathrm{km})$ could also explain the high diversity of benthic assemblages in Brittany. Moreover, macroalgae facilitate the distribution and the dispersion of numerous taxa by creating refuges from environmental stressors by providing substrate for settlement and growth (Thomsen and McGlathery, 2005; Thomaz and Cunha, 2010). Finally, within the 'temperate Northern Atlantic' realm, Brittany is a biogeographic transition zone (sensu Morrone, 2004 in Ferro and Morrone, 2014) at the boundary between the cold temperate and boreal Northern European Seas and Lusitanian provinces (Spalding et al., 2007). As such it is expected to have high species richness by harbouring species from the two biogeographic provinces. Interestingly, thermal and haline structures in the Iroise Sea can hinder dispersal between the EC and BB (Pingree et al., 1982; Boyer et al., 2009; Ayata et al., 2010) and numerous benthic species find their limit of distribution in Brittany (e.g. Cabioch et al., 1977; Grall et al, 2015; Le Duff and Grall, 2012; Quillien et al., 2012).

\subsection{Limitations}

The RESOMAR database reflects the French synergy around studies on benthic compartments. This database not only allows for the safeguard of invaluable ecological datasets, but also opens new opportunities to investigate diversity patterns at spatial scales larger than that allowed by any of the individual datasets. Bringing together these numerous and diverse datasets, covering large spatial and temporal scales, in a readily usable format constituted a great challenge, but now offers great opportunities to study ecological pattern at bioregional scales. Despite our efforts to homogenize the database and reduce the impact of 
potential confounding factors, some remain such as those induced by the specificity of each dataset as each comes from a specific research program with its own sampling design.

\section{Conclusion}

In conclusion, this study reveals macrobenthic richness distribution along the three metropolitan France seaboards. Macrobenthic richness is shown to differ between seaboards regardless of benthic habitat and the MS has the highest richness and the highest number of exclusive species. The EC hosts the lowest number of species while it is the most sampled. Owing to their proximity and more moderate barriers to dispersal, the EC and BB share a higher proportion of taxa than either shares with the MS. Finally, the investigation of latitudinal gradient along French Atlantic coasts reveals Brittany as a whole as a hotspot for macrobenthic richness, according to its transitional location between $\mathrm{BB}$ and $\mathrm{EC}$ and its habitats high diversity. This pattern is mainly constrained by hydro-climatic and topographic conditions such as hydrodynamics, complexity of the mosaic of benthic habitats, amplitudes of physical and chemical conditions, and historical processes.

In the context of global change, one would anticipate that the degree of differentiation between seaboards and latitudinal patterns may change in years to come. In such context, the RESOMAR database will surely represent as a baseline for describing and comparing macrobenthic fauna diversity patterns along French coasts.

\section{ACKNOWLEDGMENTS}

The present study was funded by the Agence Nationale de la Recherche (ANR) BenthoVAL project (ANR-13-BSV7-0006) and a Centre National de Recherche Scientifique (CNRS) grant to O. Gauthier. We sincerely thank all data providers that largely contribute to 
the development of the RESOMAR database and especially J.-M. Dewarumez, J.-M. Amouroux. We thank A. Caillo for his work on the database and on the web-interface. 


\section{REFERENCES}

Aloïsi, J.-C., Got, H., Monaco, A., 1973. Carte géomorphologique du précontinent languedocien, du Cap Bagur au Cap d'Agde, au 1/250 000 ${ }^{\mathrm{eme}}$. Scan géoréférencé http://sextant.ifremer.fr/record/db624ff0-f0be-11df-abec-005056987263/. Musée Océanographique de Monaco, Monaco.

Arvanitidis, C., Bellan, G., Drakopoulos, P., Valavanis, V., Dounas, C., Koukouras, A., Eleftheriou, A., 2002. Seascape biodiversity patterns along the Mediterranean and the Black Sea: lessons from the biogeography of benthic polychaetes. Mar. Ecol. Prog. Ser. 244, 139-152.

Ayata, S.-D., Lazure, P., Thiébaut, É., 2010. How does the connectivity between populations mediate range limits of marine invertebrates? A case study of larval dispersal between the Bay of Biscay and the English Channel (North-East Atlantic). Prog. Oceanogr. 87, 18-36.

Ayata, S.-D., Stolba, R., Comtet, T., Thiébaut, É., 2011. Meroplankton distribution and its relationship to coastal mesoscale hydrological structure in the northern Bay of Biscay (NE Atlantic). J. Plankton Res. 33, 1193-1211.

Bachelet G., Labourg P.J., Madani I., 1990. Nouvelles signalisations de Mollusques (Prosobranches et Bivalves) dans le Bassin d'Arcachon. Cah Biol Mar 31:87-92

Bachelet G., Simon-Bouhet B., Desclaux C., Garcia-Meunier P., Mairesse G., de Montaudouin X., Raigne H., Randriambao K., Sauriau P.G., Viard F., 2004. Invasion of the eastern Bay of Biscay by the nassariid gastropod Cyclope neritea: origin and effects on resident fauna, Marine Ecology Progress Series, 276, 147-159

Bazairi, H., Ben Haj, S., Boero, F., Cebrian, D., De Juan, S., Limam, A., Lleonart, J., Torchia, G., Rais, C., 2010. The Mediterranean Sea Biodiversity: state of the ecosystems, pressures, impacts and future priorities. UNEP--MAP, RCA/SPA, Tunis.

Benedetti-Cecchi, L., Cinelli, F., 1995. Habitat heterogeneity, sea urchin grazing and the distribution of algae in littoral rock pools on the west coast of Italy (western Mediterranean). Mar. Ecol. Prog. Ser. 126, 203-212.

Bianchi, C.N., Morri, C., 2000. Marine biodiversity of the Mediterranean Sea: situation, problems and prospects for future research. Mar. Pol. Bul. 40, 367-376.

Blanchet, H., Gouillieux, B., Alizier, S., Amouroux, J.-M., Bachelet, G., Barille, A.-L., Dauvin, J.-C., de Montaudouin, X., Derolez, V., Desroy, N., Grall, J., Gremare, A., Hacquebart, P., Jourde, J., Labrune, C., Lavesque, N., Meirland, A., Nebout, T., Olivier, F., Pelaprat, C., Ruellet, T., Sauriau, P.-G., Thorin, S., 2014. Multiscale patterns in the diversity and organization of benthic intertidal fauna among French Atlantic estuaries. J. Sea Res. 90, 95-110.

Bonifácio, P., Bourgeois, S., Labrune, C., Amouroux, J.M., Escoubeyrou, K., Buscail, R., Romero-Ramirez, A., Lantoine, F., Vétion, G., Bichon, S., Desmalades, M., Rivière, B., Deflandre, B., Grémare, A., 2014. Spatiotemporal changes in surface sediment characteristics and benthic macrofauna composition off the Rhône River in relation to its hydrological regime. Estuarine, Coastal and Shelf Science 151, 196-209. doi:10.1016/j.ecss.2014.10.011

Bonsdorff, E., 2006. Zoobenthic diversity-gradients in the Baltic Sea: continuous post-glacial succession in a stressed ecosystem. J. Exp. Mar. Biol. Ecol. 330, 383-391.

Bourrin, F., Durrieu de Madron, X., 2006. Contribution to the study of coastal rivers and associated prodeltas to sediment supply in the Gulf of Lions (NW Mediterranean Sea). Vie Milieu 56, 307-314. 
Boyer, K.E., Kertesz, J.S., Bruno, J.F., 2009. Biodiversity effects on productivity and stability of marine macroalgal communities: the role of environmental context. Oikos 118, 1062-1072.

Brose, U., Martinez, N.D., Williams, R.J., 2003. Estimating species richness: sensitivity to sample coverage and insensitivity to spatial patterns. Ecology 84, 2364-2377.

Burnham, K.P., Overton, W.S., 1978. Estimation of the size of a closed population when capture probabilities vary among animals. Biometrika 65, 625-633.

Burnham, K.P., Overton, W.S., 1979. Robust estimation of population size when capture probabilities vary among animals. Ecology 60, 927-936.

Cabioch, L., 1968. Contribution à la connaissance des peuplements benthiques de la Manche occidentale. Cah. Biol. Mar. 9, 492-720.

Cabioch, L., Gentil, F., Glaçon, R., Retière, C., 1977. Le macrobenthos des fonds meubles de la Manche : distribution générale et écologie, in: Keegan, B.F., O'Ceidigh, P., Boaden, P.J.S. (Eds.), Biology of Benthic Organisms. Proc. $11^{\text {th }}$ European Marine Biology Symposium, Galway, October 1976. Pergamon Press, Oxford, pp. 115-128.

Cabral, P., Levrel, H., Schoenn, J., Thiébaut, E., Le Mao, P., Mongruel, R., Rollet, C., Dedieu, K., Carrier, S., Morisseau, F., Daures, F., 2015. Marine habitats ecosystem service potential: A vulnerability approach in the Normand-Breton (Saint Malo) Gulf, France. Ecosystem Services 16, 306-318.

Chao, A., 1987. Estimating the population size for capture-recapture data with unequal catchability. Biometrics 43, 783-791.

Chassé, C., Glémarec, M., Guillou, J., Hily, C., 1978. Répartition des biomasses de la macrofaune endogée des sédiments meubles du golfe de Gascogne (nord et centre). J. Rech. Océanogr. 4, 3-9.

Chaudhary, C., Saeedi, H., Costello, M.J., Bimodality of latitudinal gradients in marine species richness. Trends Ecol. Evol. 31, 670-676.

Cimmaruta, R., Bondanelli, P., Nascetti, G., 2005. Genetic structure and environmental heterogeneity in the European hake (Merluccius merluccius). Mol. Ecol. 14, 25772591.

Clarke, A., Lidgard, S., 2000. Spatial patterns of diversity in the sea: bryozoan species richness in the North Atlantic. J. Anim. Ecol. 69, 799-814.

Cleveland, W., Grosse, E., Shyun, W., 1991. Local regression models. Chapter 8, in: Chambers, J.M., Hastie, T.J. (Eds.), Statistical Models in S. Chapman \& Hall/CRC Press, London.

Cognetti, G., Maltagliati, F., 2000. Biodiversity and adaptive mechanisms in brackish water fauna. Mar. Pol. Bul. 40, 7-14.

Coll, M., Piroddi, C., Steenbeek, J., Kaschner, K., Ben Rais Lasram, F., Aguzzi, J., Ballestrtos, E., 2010. The Biodiversity of the Mediterranean Sea: estimates, patterns, and threats. PLoS ONE 5(8): e11842.

Copertino, M., Connell, S.D., Cheshire, A., 2005. The prevalence and production of turfforming algae on a temperate subtidal coast. Phycologia 44, 241-248.

Cowen, R.K., Sponaugle, S., 2009. Larval dispersal and marine population connectivity. Annu. Rev. Mar. Sci. 1, 443-466.

Crame, J.A., 2000. Evolution of taxonomic diversity gradients in the marine realm: evidence from the composition of Recent bivalve faunas. Paleobiology 26, 188-214.

Dauvin, J.-C., 2015. History of benthic research in the English Channel: From general patterns of communities to habitat mosaic description. J. Sea Res. 100, 32-45. 
Dauvin, J.-C., Bachelet, G., Bellan, G., 2006. Biodiversity and biogeographic relationships of the polychaete fauna in French Atlantic and Mediterranean waters. Sci. Mar. (Barc.) 70S3, 259-267.

Dauvin, J.-C., Bellan-Santini, D., 2004. Biodiversity and the biogeographic relationships of the Amphipoda: Gammaridea on the French coastline. J. Mar. Biol. Ass. U. K. 84, 621-628.

Dauvin, J.-C., Kendall, M., Paterson, G., Gentil, F., Jirkov, I., Sheader, M., de Lange, M., 1994. An initial assessment of polychaete diversity in the Northeastern Atlantic Ocean. Biodiversity Letters 2, 171-181.

Davies, J., Baxter, J.M., Bradley, M.C., D., Khan, J., Murray, E., Sanderson, W., Turnbull, C., Vincent, M., 2001. Marine Monitoring Handbook. Joint Nature Conservation Committee, Peterborough.

Dinter, W.P., 2001. Biogeography of the OSPAR Maritime Area: a synopsis and synthesis of biogeographical distribution patterns described for the North-East Atlantic. Federal Agency for Nature Conservation, Bonn.

Dornelas, M., Gotelli, N.J., McGill, B., Shimadzu, H., Moyes, F., Sievers, C., Magurran, A.E., 2014. Assemblage Time Series Reveal Biodiversity Change but Not Systematic Loss. Science 344, 296-299. doi:10.1126/science.1248484

Doti, B.L., Roccatagliata, D., López Gappa, J., 2014. An inverse latitudinal biodiversity pattern in asellote isopods (Crustacea, Peracarida) from the Southwest Atlantic between $35^{\circ}$ and $56^{\circ} \mathrm{S}$. Marine Biodiversity 44, 115-125.

Durrieu de Madron, X., Abassi, A., Heussner, S., Monaco, A., Aloisi, J.C., Radakovitch, O., Giresse, P., Buscail, R., Kerherve, P., 2000. Particulate matter and organic carbon budgets for the Gulf of Lions (NW Mediterranean). Oceanol. Acta 23, 717-730.

Dworschak, P.C., 2000. Global diversity in the Thalassinidea (Decapoda). J. Crustac. Biol. 20 (5), 238-245.

Ehrhold, A., Hamon, D., Chevalier, C., 2011. Réseau de surveillance benthique (REBENT) Région Bretagne. Approche sectorielle subtidale : Identification et caractérisation des habitats benthiques $\mathrm{du}$ secteur Morlaix. Rapport Ifremer RST/IFREMER/ODE/DYNECO/Ecologie benthique/11-03/REBENT. Ifremer, Plouzané.

Ehrhold, A., Hamon, D., Guillaumont, B., 2006. The REBENT monitoring network, a spatially integrated, acoustic approach to surveying nearshore macrobenthic habitats: application to the Bay of Concarneau (South Brittany, France). ICES J. Mar. Sci.: J. Cons. 63, 1604-1615.

Ellingsen, K., Gray, J.S., 2002. Spatial patterns of benthic diversity: is there a latitudinal gradient along the Norwegian continental shelf? J. Anim. Ecol. 71, 373-389.

Ferro, I., Morrone, J.J., 2014. Biogeographical transition zones: a search for conceptual synthesis. Biol. J. Linn. Soc. 113, 1-12.

Foveau, A., Desroy, N., Dauvin, J.C., Dewarumez, J.M., 2013. Distribution patterns in the benthic diversity of the eastern English Channel. Mar. Ecol. Prog. Ser. 479, 115-126.

Gallon, R.K., Robuchon, M., Leroy, B., Le Gall, L., Valero, M., Feunteun, E., 2014. Twenty years of observed and predicted changes in subtidal red seaweed assemblages along a biogeographical transition zone: inferring potential causes from environmental data. J. Biogeogr. 41, 2293-2306.

Galparsoro, I., Connor, D.W., Borja, Á., Aish, A., Amorim, P., Bajjouk, T., Chambers, C., Coggan, R., Dirberg, G., Ellwood, H., Evans, D., Goodin, K.L., Grehan, A., Haldin, J., Howell, K., Jenkins, C., Michez, N., Mo, G., Buhl-Mortensen, P., Pearce, B., Populus, 
J., Salomidi, M., Sánchez, F., Serrano, A., Shumchenia, E., Tempera, F., Vasquez, M., 2012. Using EUNIS habitat classification for benthic mapping in European seas: Present concerns and future needs. Mar. Pol. Bul. 64, 2630-2638.

Glémarec, M., 1964. Bionomie benthique de la partie orientale du golfe du Morbihan. Cah. Biol. Mar. 5, 33-96.

Glémarec, M., 1969. Les peuplements benthiques du plateau continental nord-Gascogne. Thèse de Doctorat d'Etat es Sciences Naturelles, Faculté des Sciences, Brest. Faculté des Sciences de Paris, Paris, p. 167.

Goulletquer P, Bachelet G, Sauriau PG, Noel P., 2002. Open Atlantic coast of Europe - a century of introduced species into French waters. In: Leppäkoski E, Gollasch S, Olenin S (eds) Invasive aquatic species of Europe. Distribution, impacts and management. Kluwer Academic Publishers,Dordrecht, p 276-290

Grall, J., Glémarec, M., 1997. Biodiversité des fonds de maerl en Bretagne : approche fonctionnelle et impacts anthropiques. Vie Milieu 47, 339-349.

Grall, J., Serre-Arnoldy, D., Serre, S., Quillien, N., 2015. Première signalisation du nudibranche aeolidien Spurilla neapolitana en mer d'Iroise (Bretagne ouest). An aod les cahiers naturalistes de l'Observatoire marin 4, 29-33.

Gray, J.S., 2000. The measurement of marine species diversity, with an application to the benthic fauna of the Norwegian continental shelf. J. Exp. Mar. Biol. Ecol. 250, 23-49.

Gray, J.S., 2002. Species richness of marine soft sediments. Mar. Ecol. Prog. Ser. 244, 285 297.

Harley, C.D.G., Randall Hughes, A., Hultgren, K.M., Miner, B.G., Sorte, C.J.B., Thornber, C.S., Rodriguez, L.F., Tomanek, L., Williams, S.L., 2006. The impacts of climate change in coastal marine systems. Ecology Letters 9, 228-241. doi:10.1111/j.14610248.2005.00871.x

Hawkins SJ., Sugden HE., Mieszkowska N., Moore PJ., Poloczanska E., Leaper R., Herbert RJH.,Genner MJ., Moschella PS., Thompson RC., Jenkins SR., Southward AJ., Burrows MT., 2009. Consequences of climate-driven biodiversity changes for ecosystem functioning of North European rocky shores. Mar Ecol-Prog Ser 396:245259

Heip, C., Basford, D., Craeymeersch, J.A., Dewarumez, J.M., Dörjes, J., de Wilde, P., Duineveld, G., Eleftheriou, A., Herman, P.M.J., Niermann, U., Kingston, P., Künitzer, A., Rachor, E., Rumohr, H., Soetaert, K., Soltwedel, T., 1992. Trends in biomass, density and diversity of North Sea macrofauna. ICES J. Mar. Sci.: J. Cons. 49, 13-22.

Hillebrand, H., 2004. Strength, slope and variability of marine latitudinal gradients. Mar. Ecol. Prog. Ser. 273, 251-267.

Hinz H., Capasso E., Lilley M., Frost M., Jenkins SR., 2011. Temporal differences across a biogeographical boundary reveal slow response of sub-littoral benthos to climate change. Mar Ecol-Prog Ser 423:69-82

Hiscock, K., Southward, A., Tittley, I., Hawkins, S., 2004. Effects of changing temperature on benthic marine life in Britain and Ireland. Aquat. Conserv.: Mar. Freshwater Ecosystems 14, 333-362.

Holme, N.A., 1966. The bottom fauna of the English Channel. Part II. J. Mar. Biol. Ass. U. K. 46, 401-493.

Hortal, J., Borges, P.A.V., Gaspar, C., 2006. Evaluating the performance of species richness estimators: sensitivity to sample grain size. J. Anim. Ecol. 75, 274-287.

Hsieh, T.C., Ma, K.H., Chao, A., 2016. Method Ecol. Evol. DOI: 10.1111/2041-210X.12613. 
Hummel, H., Van Avesaath, P., Wijnhoven, S., Kleine-Schaars, L., Degraer, S., Kerckhof, F., Bojanic, N., Skejic, S., Vidjak, O., Rousou, M., Orav-Kotta, H., Kotta, J., Jourde, J., Pedrotti, M.L., Leclerc, J.-C., Simon, N., Rigaut-Jalabert, F., Bachelet, G., Lavesque, N., Arvanitidis, C., Pavloudi, C., Faulwetter, S., Crowe, T., Coughlan, J., BenedettiCecchi, L., Dal Bello, M., Magni, P., Como, S., Coppa, S., Ikauniece, A., Ruginis, T., Jankowska, E., Weslawski, J.M., Warzocha, J., Gromisz, S., Witalis, B., Silva, T., Ribeiro, P., Fernandes De Matos, V.K., Sousa-Pinto, I., Veiga, P., Troncoso, J., Guinda, X., Juanes De La Pena, J.A., Puente, A., Espinosa, F., Pérez-Ruzafa, A., Frost, M., McNeill, C.L., Peleg, O., Rilov, G., 2016. Geographic patterns of biodiversity in European coastal marine benthos. J. Mar. Biol. Ass. U. K., 1-17.

Hutchings, P., 1998. Biodiversity and functioning of polychaetes in benthic sediments. Biodivers. Conserv. 7, 1133-1145.

Hutchinson, G.E., 1959. Homage to Santa Rosalia or why are there so many kinds of animals? Am. Nat. 93, 145-159.

Jolly, M.T., Viard, F., Gentil, F., ThiéBaut, E., Jollivet, D., 2006. Comparative phylogeography of two coastal polychaete tubeworms in the Northeast Atlantic supports shared history and vicariant events. Mol. Ecol. 15, 1841-1855.

Kark, S., van Rensburg, B.J., 2006. Ecotones: marginal or central areas of transition? Isr. J. Ecol. Evol. 52, 29-53.

Kerswell, A.P., 2006. Global biodiversity patterns of benthic marine algae. Ecology 87, 24792488.

Kinlan, B.P., Gaines, S.D., 2003. Propagule dispersal in marine and terrestrial environments: a community perspective. Ecology 84, 2007-2020.

Knox, G., 1977. The role of annelids in benthic soft-bottom communities, in: Reish, D.J., Fauchald, K. (Eds.), Essays on polychaetous annelids : in memory of Dr. Olga Hartman. Allan Hancock Foundation, University of Southern California, Los Angeles, pp. 547-604.

Labrune, C., Grémare, A., Amouroux, J.-M., Sardá, R., Gil, J., Taboada, S., 2008. Structure and diversity of shallow soft-bottom benthic macrofauna in the Gulf of Lions (NW Mediterranean) Helgol. Mar. Res. 62, 201-214.

Le Duff, M., Gral, J., 2012. Les espèces de mollusques en limite nord de répartition à la pointe de Bretagne I. Ranella olearium (Linnaeus, 1758). An aod - les cahiers naturalistes de l'Observatoire marin 1, 9-13.

Le Loc'h, F., Hily, C., Grall, J., 2008. Benthic community and food web structure on the continental shelf of the Bay of Biscay (North Eastern Atlantic) revealed by stable isotopes analysis. J. Mar. Syst. 72, 17-34.

Lee, S.-M., Chao, A., 1994. Estimating population size via sample coverage for closed capture-recapture models. Biometrics 50, 88-97.

Levin, L.A., Etter, R.J., Rex, M.A., Gooday, A.J., Smith, C.R., Pineda, J., Stuart, C.T., Hessler, R.R., Pawson, D., 2001. Environmental influences on regional deep-sea species diversity. Annu. Rev. Ecol. Syst. 32, 51-93.

Lourido, A., Moreira, J., Troncoso, J.S., 2008. Assemblages of peracarid crustaceans in subtidal sediments from the Ría de Aldán (Galicia, NW Spain). Helgol. Mar. Res. 62, 289-301.

Macpherson, E., 2002. Large-scale species-richness gradients in the Atlantic Ocean. Proc. R. Soc. Lond. B: Biol. Sci. 269, 1715.

Marchais, V., Schaal, G., Grall, J., Lorrain, A., Nerot, C., Richard, P., Chauvaud, L., 2013. Spatial variability of stable isotope ratios in oysters (Crassostrea gigas) and primary 
producers along an estuarine gradient (Bay of Brest, France). Estuaries and Coasts 36, 808-819.

McArthur, M.A., Brooke, B.P., Przeslawski, R., Ryan, D.A., Lucieer, V.L., Nichol, S., McCallum, A.W., Mellin, C., Cresswell, I.D., Radke, L.C., 2010. On the use of abiotic surrogates to describe marine benthic biodiversity. Estuar. Coast. Shelf Sci. 88, 21-32.

Mieszkowska N., Hawkins SJ., Burrows MT., Kendall MA., 2007. Long-term changes in the geographic distribution and population structures of Osilinus lineatus (Gastropoda :Trochidae) in Britain and Ireland. J Mar Biol Assoc UK 87:537-545

Miller, R.J., Reed, D.C., Brzezinski, M.A., 2009. Community structure and productivity of subtidal turf and foliose algal assemblages. Mar. Ecol. Prog. Ser. 388, 1-11.

Millot, C., 1999. Circulation in the Western Mediterranean Sea. J. Mar. Syst. 20, 423-442.

Morrone, J.J., 2004. Panbiogeografía, componentes bióticos y zonas de transición. Rev. Bras. Entomol. 48, 149-162.

Narayanaswamy, B.E., Renaud, P.E., Duineveld, G.C.A., Berge, J., Lavaleye, M.S.S., Reiss, H., Brattegard, T., 2010. Biodiversity trends along the Western European margin. PLoS ONE 5, e14295.

Nunes, A.L., Katsanevakis, S., Zenetos, A., Cardoso, A.C., 2014. Gateways to alien invasions in the European seas. Aquat. Invasions 9, 133-144.

Occhipinti-Ambrogi, A., 2007. Global change and marine communities: Alien species and climate change. Marine Pollution Bulletin, Marine Bioinvasions: A collection of reviews 55, 342-352. doi:10.1016/j.marpolbul.2006.11.014

Olden J.D. and Rooney T.P. (2006) On defining and quantifying biotic homogenization. Globa Ecology and Biogeography, 15, 113-120

Oksanen, J., Blanchet, F.G., Friendly, M., Kindt, R., Legendre, P., McGlinn, D., Minchin, P.R., O'Hara, R.B., Simpson, G.L., Solymos, P., Stevens, M.H.H., Szoecs, E., Wagne, H., 2015. Package 'vegan'. Community Ecology package. https://CRAN.Rproject.org/package=vegan.

Ooms, J., James, d., DebRoy, S., Wickham, H., Horner, J., 2016. Package 'RMySQL'. Package 'RMySQL'. https://cran.r-project.org/web/packages/RMySQL/index.html.

Pérès, J.-M., 1967. The Mediterranean benthos. Oceanogr. Mar. Biol. Ann. Rev. 5, 449-533.

Pezy, J.-P., Dauvin, J.-C., 2016. Extension of the geographical distribution of the crab Asthenognathus atlanticus Monod, 1932, in the eastern English Channel through its commensal relationship with the polychaete Chaetopterus variopedatus (Renier, 1804). Mar Biodiv 1-7.

Philippart, C.J.M., van Aken, H.M., Beukema, J.J., Bos, O.G., Cadée, G.C., Dekker, R., 2003. Climate-related changes in recruitment of the bivalve Macoma balthica. Limnol. Oceanogr. 48, 2171-2185.

Pingree, R.D., Mardell, G.T., Holligan, P.M., Griffiths, D.K., Smithers, J., 1982. Celtic Sea and Armorican current structure and the vertical distributions of temperature and chlorophyll. Cont. Shelf Res. 1, 99-116.

Pinsky ML., Worm B., Fogarty MJ., Sarmiento JL., Levin SA., 2013. Marine Taxa Track Local Climate Velocities. Science 341:1239-1242

Poloczanska ES., Brown CJ., Sydeman WJ., Kiessling W., Schoeman DS., Moore PJ., Brander K., Bruno JF., Buckley LB., Burrows MT., Duarte CM., Halpern BS., Holding J., Kappel CV., O'Connor MI., Pandolfi JM., Parmesan C., Schwing F., Thompson SA., Richardson AJ., (2013) Global imprint of climate change on marine life. Nat Clim Chang 3:919-925 
Prato, E., Biandolino, F., 2005. Amphipod biodiversity of shallow water in the Taranto seas (north-western Ionian Sea). J. Mar. Biol. Ass. U. K. 85, 333-338.

Quillien, N., Le Garrec, V., Grall, J., 2012. Nouvelles données sur la limite de distribution septentrionale d'Onuphis eremita (Audouin \& Milne Edwards, 1833) An aod - les cahiers naturalistes de l'Observatoire marin 1, 15-19.

R Core Team, 2015. R: A Language and Environment for Statistical Computing. R Foundation for Statistical Computing, Vienna, Austria. URL https://www.Rproject.org/.

Rees, H.L., Pendle, M.A., Waldock, R., Limpenny, D.S., Boyd, S.E., 1999. A comparison of benthic biodiversity in the North Sea, English Channel, and Celtic Seas. ICES J. Mar. Sci. 56, 228-246.

Retière, C., 1979. Contribution à la connaissance des peuplements benthiques du glofe normanno-breton. Université Rennes 1, p. 431.

Rex, M.A., Stuart, C.T., Hessler, R.R., Allen, J.A., Sanders, H.L., Wilson, G.D.F., 1993. Global-scale latitudinal patterns of species diversity in the deep-sea benthos. Nature $365,636-639$.

Roy, K., Jablonski, D., Valentine, J.W., 2000. Dissecting latitudinal diversity gradients: functional groups and clades of marine bivalves. Proc. R. Soc. Lond. B: Biol. Sci. 267, 293.

Roy, K., Jablonski, D., Valentine, J.W., Rosenberg, G., 1998. Marine latitudinal diversity gradients: Tests of causal hypotheses. PNAS 95, 3699-3702.

Sanders, H.L., 1968. Marine benthic diversity: a comparative study. Am. Nat. 102, 243-282.

Santelices, B., Bolton, J.J., Meneses, I., 2009. Marine algal communities, in: Witman, J.D., Roy, K. (Eds.), Marine macroecology. University of Chicago Press, Chicago \& London, pp. 153-192.

Schaal, G., Riera, P., Leroux, C., 2008. Trophic coupling between two adjacent benthic food webs within a man-made intertidal area: a stable isotopes evidence. Estuar. Coast. Shelf Sci. 77, 523-534.

Sokołowski, A., Wołowicz, M., Asmus, H., Asmus, R., Carlier, A., Gasiunaité, Z., Grémare, A., Hummel, H., Lesutiené, J., Razinkovas, A., Renaud, P.E., Richard, P., Kędra, M., 2012. Is benthic food web structure related to diversity of marine macrobenthic communities? Estuar. Coast. Shelf Sci. 108, 76-86.

Spalding, M.D., Fox, H.E., Allen, G.R., Davidson, N., Ferdaña, Z.A., Finlayson, M., Halpern, B.S., Jorge, M.A., Lombana, A., Lourie, S.A., Martin, K.D., McManus, E., Molnar, J., Recchia, C.A., Robertson, J., 2007. Marine ecoregions of the world: A bioregionalization of coastal and shelf areas. BioScience 57, 573-583.

Stride, A.H., 1973. Sediment transport by the North Sea, in: Goldberg, E.D. (Ed.), North Sea Science. The M.I.T. Press, Cambridge, Massachusetts, pp. 101-130.

Terborgh, J., 1973. On the notion of favorableness in plant ecology. Am. Nat. 107, 481-501.

Thomaz, S.M., da Cunha, E.R., 2010. The role of macrophytes in habitat structuring in aquatic ecosystems: methods of measurement, causes and consequences on animal assemblages' composition and biodiversity. Acta Limnol. Bras. 22, 218-236.

Thomsen, M.S., McGlathery, K., 2005. Facilitation of macroalgae by the sedimentary tube forming polychaete Diopatra cuprea. Estuar. Coast. Shelf Sci. 62, 63-73.

Tyler, A.C., McGlathery, K.J., Anderson, I.C., 2001. Macroalgae mediation of dissolved organic nitrogen fluxes in a temperate coastal lagoon. Estuar. Coast. Shelf Sci. 53, 155-168. 
Van Hoey, G., Degraer, S., Vincx, M., 2004. Macrobenthic community structure of softbottom sediments at the Belgian Continental Shelf. Estuar. Coast. Shelf Sci. 59, 599613.

Vandepitte, L., Vanhoorne, B., Kraberg, A., Anisimova, N., Antoniadou, C., Araújo, R., Bartsch, I., Beker, B., Benedetti-Cecchi, L., Bertocci, I., Cochrane, S., Cooper, K., Craeymeersch, J., Christou, E., Crisp, D.J., Dahle, S., de Boissier, M., de Kluijver, M., Denisenko, S., De Vito, D., Duineveld, G., Escaravage, V., Fleischer, D., Fraschetti, S., Giangrande, A., Heip, C., Hummel, H., Janas, U., Karez, R., Kedra, M., Kingston, P., Kuhlenkamp, R., Libes, M., Martens, P., Mees, J., Mieszkowska, N., Mudrak, S., Munda, I., Orfanidis, S., Orlando-Bonaca, M., Palerud, R., Rachor, E., Reichert, K., Rumohr, H., Schiedek, D., Schubert, P., Sistermans, W.C.H., Pinto, I.S., Southward, A.J., Terlizzi, A., Tsiaga, E., van Beusekom, J.E.E., Vanden Berghe, E., Warzocha, J., Wasmund, N., Weslawski, J.M., Widdicombe, C., Wlodarska-Kowalczuk, M., Zettler, M.L., 2010. Data integration for European marine biodiversity research: creating a database on benthos and plankton to study large-scale patterns and long-term changes. Hydrobiologia 644, 1-13.

Vavrek, M.J., 2011. fossil: Palaeoecological and palaeogeographical analysis tools. Palaeontol. Electron. 14.1.1T.

Warwick, R.M., Uncles, R.J., 1980. Distribution of benthic macrofauna associations in the Bristol Channel in relation to tidal stress. Mar. Ecol. Prog. Ser. 3, 97-103.

Wethey, D.S., Woodin, S.A., 2008. Ecological hindcasting of biogeographic responses to climate change in the European intertidal zone. Hydrobiologia 606, 139-151.

Wienche, C., Bischof, K., 2012. Seaweeds biology: novel insights into ecophysiology, ecology and utilization, Ecological Studies. Springer-Verlag, Berlin Heidelberg, p. 514.

Wiens, J.A., 1989. Spatial scaling in ecology. Funct. Ecol. 3, 385-397.

Willig, M.R., Kaufman, D.M., Stevens, R.D., 2003. Latitudinal gradients of biodiversity: Pattern, process, scale, and synthesis. Annu. Rev. Ecol. Evol. Syst. 34, 273-309. 
Table 1: Observed species richness $(\mathrm{S})$, total number of individuals $(\mathrm{N})$, estimates of total species richness (ICE, Chao2, Jackknife1) and number of sampling occasions for the three seaboards and subtidal sediment habitats (A5.1: sublittoral coarse sediment; A5.2: sublittoral sand; A5.3: sublittoral mud; A5.4: sublittoral mixed sediments, NA: subtidal sediment habitats defined to higher level).

\begin{tabular}{|c|c|c|c|c|c|c|}
\hline & $\mathbf{S}$ & $\mathbf{N}$ & ICE & Chao2 J & Jackknife1 & Number of sampling \\
\hline English Channel (EC) & 1,042 & $1,654,849$ & $1,104.9$ & $1,239.9$ & $1,237.9$ & 1,520 \\
\hline A5.1 & 281 & 5,810 & 318.5 & 364.8 & 375.3 & 47 \\
\hline A5.2 & 729 & $1,253,050$ & 789.7 & 922.9 & 894.9 & 1,069 \\
\hline A5.3 & 377 & 202,207 & 419.0 & 482.1 & 484.9 & 80 \\
\hline A5.4 & 490 & 91,065 & 528.7 & 590.1 & 606.3 & 163 \\
\hline NA & 664 & 102,717 & 723.8 & 827.7 & 834.4 & 161 \\
\hline Bay of Biscay (BB) & 1,607 & 620,577 & $1,692.1$ & $1,850.1$ & $1,877.9$ & 2,954 \\
\hline A5.1 & 573 & 8,864 & 659.9 & 811.4 & 777.7 & 680 \\
\hline A5.2 & 1,040 & 119,527 & $1,124.5$ & $1,268.6$ & $1,293.8$ & 993 \\
\hline A5.3 & 860 & 208,133 & 942.4 & $1,130.1$ & $1,095.7$ & 700 \\
\hline A5.4 & 703 & 22,552 & 777.5 & 887.7 & 912.3 & 241 \\
\hline NA & 971 & 261,501 & $1,039.3$ & $1,143.4$ & $1,171.8$ & 340 \\
\hline Mediterranean Sea (MS) & 1,765 & 604,706 & $1,895.4$ & $2,137.3$ & $2,150.8$ & 841 \\
\hline A5.1 & 326 & 13,672 & 389.0 & 478.0 & 458.9 & 31 \\
\hline A5.2 & 655 & 36,594 & 743.2 & 966.8 & 872.4 & 145 \\
\hline A5.3 & 861 & 48,741 & 963.5 & $1,135.4$ & $1,119.5$ & 184 \\
\hline A5.4 & 730 & 21,120 & 843.5 & $1,073.8$ & 993.0 & 59 \\
\hline NA & 1,254 & 484,579 & $1,357.2$ & $1,595.3$ & $1,558.4$ & 422 \\
\hline
\end{tabular}


Table 2: Observed species richness (S), total number of individuals $(\mathrm{N})$, and Number of sampling occasions $(F)$ for each taxonomic group of the soft-bottom subset. Numbers into brackets give the percentages of total observed richness for each group.

\begin{tabular}{|c|c|c|c|}
\hline & $\mathrm{S}$ & $\mathrm{N}$ & $\mathrm{F}$ \\
\hline Annelida & $852(32.5)$ & $\begin{array}{l}1,431,006 \\
(49.7)\end{array}$ & $\begin{array}{l}4,858 \\
(91.4)\end{array}$ \\
\hline Arthropoda & 754 (28.7) & $\begin{array}{l}935,234 \\
(32.5)\end{array}$ & $\begin{array}{l}3,930 \\
(73.9)\end{array}$ \\
\hline Mollusca & $543(20.7)$ & $\begin{array}{l}308,506 \\
(10.71)\end{array}$ & $\begin{array}{l}4,078 \\
(76.7)\end{array}$ \\
\hline Cnidaria & $138(5.3)$ & $10,387(0.4)$ & $\begin{array}{l}1,613 \\
(30.3)\end{array}$ \\
\hline Echinodermata & $127(4.8)$ & $70,990(2.46)$ & $\begin{array}{l}3,266 \\
(61.4)\end{array}$ \\
\hline Chordata & $82(3.1)$ & $3,295(0.1)$ & $776(14.6)$ \\
\hline Porifera & $43(1.6)$ & $227(0.01)$ & $101(1.9)$ \\
\hline Bryozoa & $32(1.2)$ & $185(0.01)$ & $143(2.7)$ \\
\hline Sipuncula & $24(0.9)$ & $49,445(1.7)$ & $\begin{array}{l}1,400 \\
(26.3)\end{array}$ \\
\hline Echiura & $8(0.3)$ & $117(0.004)$ & $58(1.1)$ \\
\hline Brachiopoda & $8(0.3)$ & $807(0.03)$ & $59(1.1)$ \\
\hline Hemichordata & $7(0.3)$ & $166(0.01)$ & $72(1.4)$ \\
\hline
\end{tabular}




Phoronida $\quad 6(0.2) \quad 69,769(2.42) \quad 418(7.9)$

Table 3: Pairwise percentages of shared species between seaboards of the soft-bottom subset as obtained by a constrained rarefaction procedure (see Material and methods for details). Values correspond to proportions of species shared between two seaboards relative to the total number of species in the two seaboards. (EC: English Channel; BB: Bay of Biscay; MS: Mediterranean Sea).

\begin{tabular}{llcl}
\hline & & EC & BB \\
\hline BB & All taxa & 49.7 & \\
& Polychaeta & 58.4 & \\
& Arthropoda & 55.5 & \\
& Mollusca & 44.2 & \\
& Echinodermata & 39 & \\
MS & All taxa & 27.6 & 34.1 \\
& Polychaeta & 34.4 & 41.9 \\
& Arthropoda & 26.8 & 28.8 \\
& Mollusca & 24.4 & 35.2 \\
& Echinodermata & 20.8 & 35.1 \\
\hline
\end{tabular}




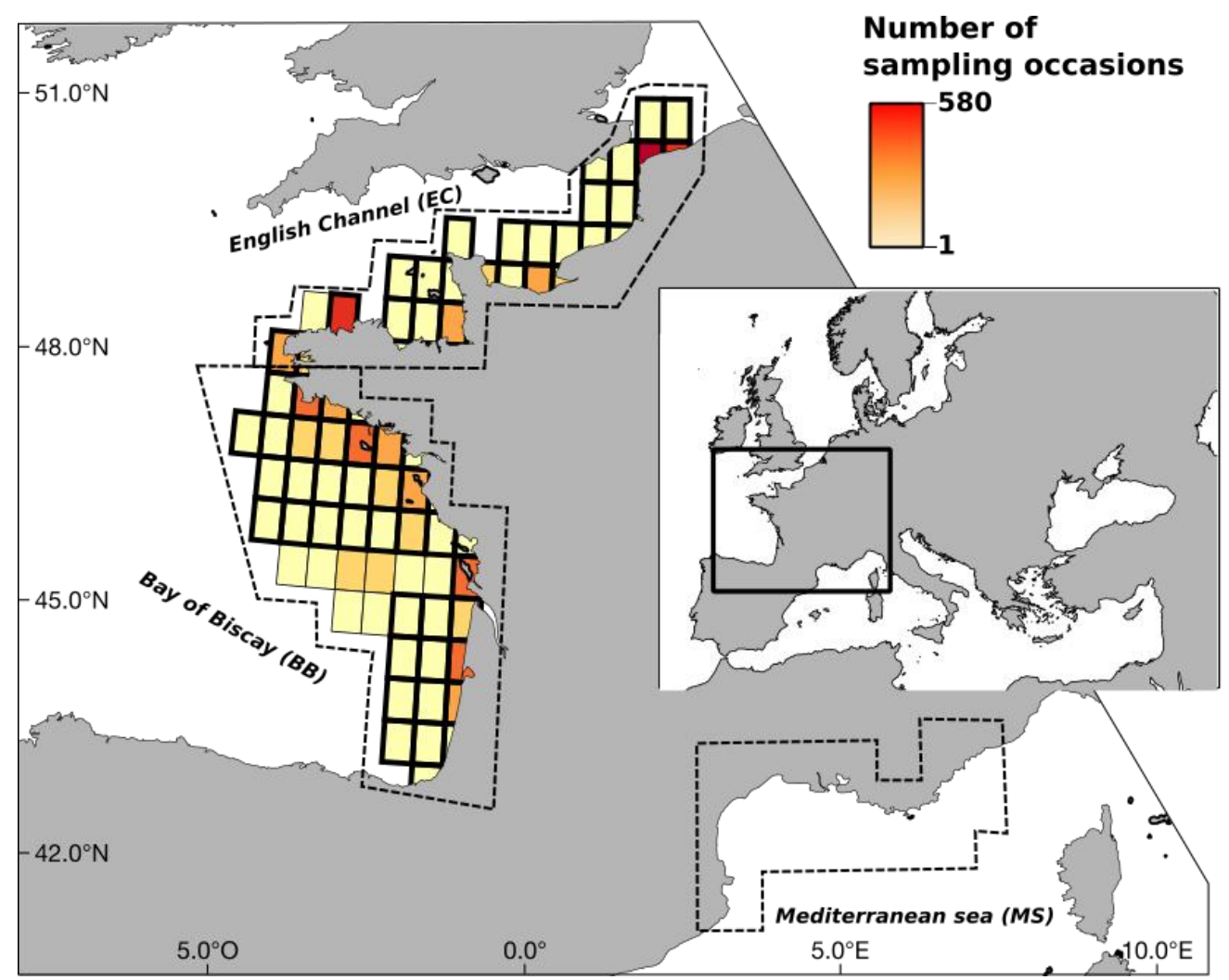

Fig. 1: Spatial scope of the RESOMAR Benthos Database. Records cover a 50-years period (1961 to 2011). Sampling effort expressed as the number of sampling occasions is represented in each cell $(0.5 \times 0.5$ degree grid size $)$. Only cells used to investigate latitudinal pattern of microbenthic richness were shown. Stations selected in this study are located in cells with thick borders. 

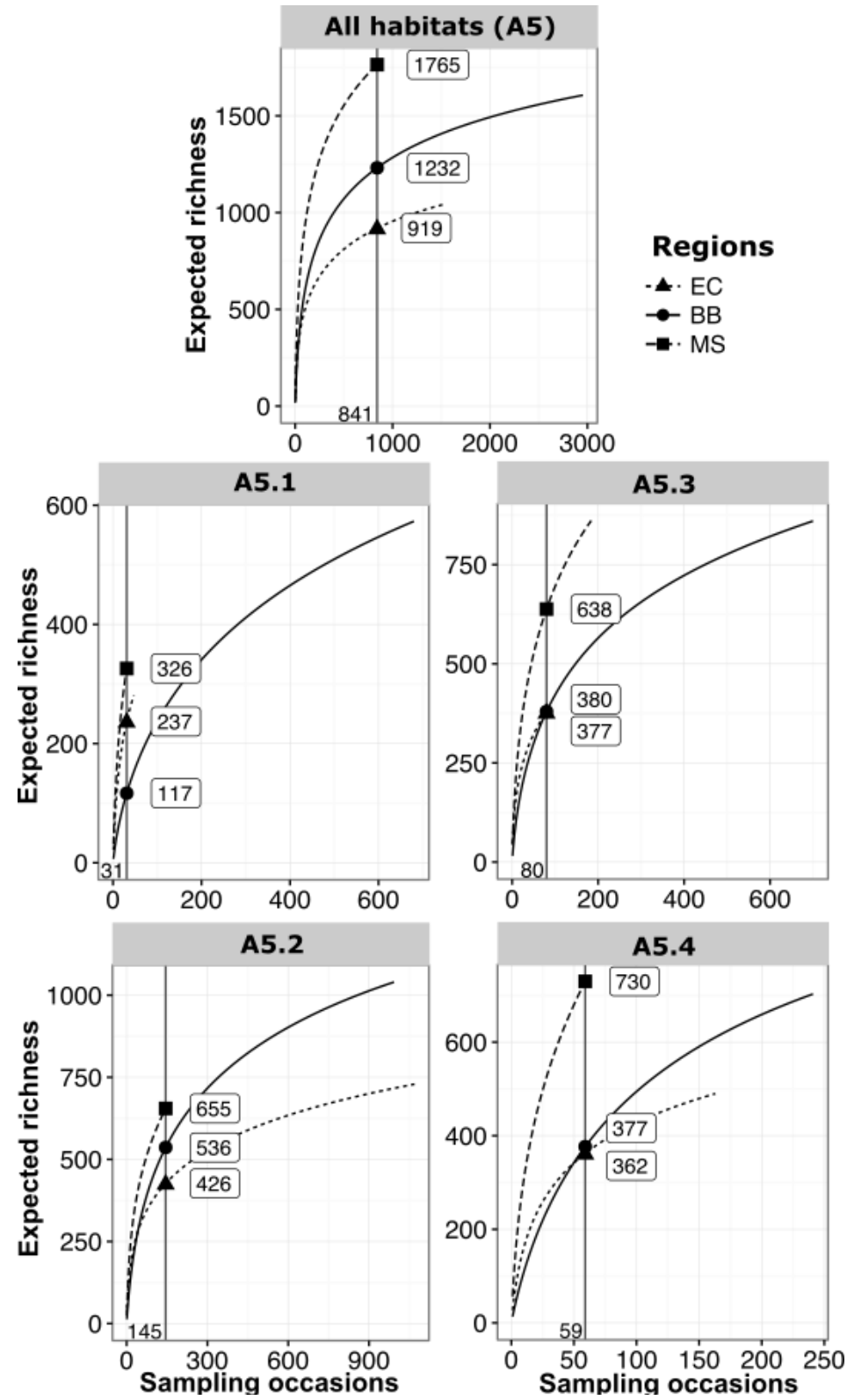

Fig. 2: Sample-based rarefaction of benthic macro-invertebrates on the subtidal soft sediments subset (A5.1: sublittoral coarse sediment; A5.2: sublittoral sand; A5.3: sublittoral mud; A5.4: sublittoral mixed sediments) within each seaboard (EC: English Channel; BB: Bay of Biscay; MS: Mediterranean Sea). The vertical line represents the minimum effort. 

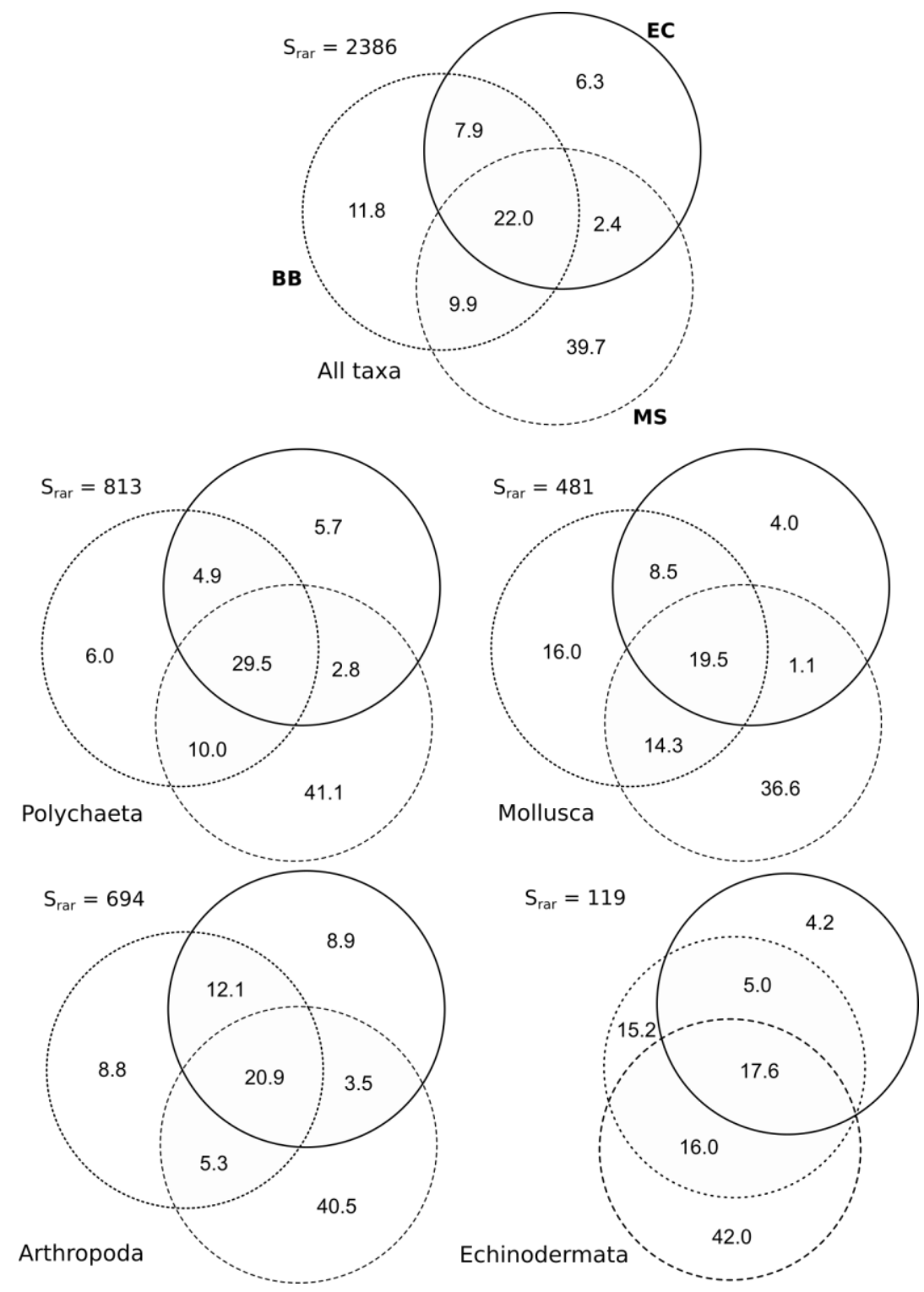

Fig. 3: Venn diagram obtained by a constrained rarefaction procedure (see Material and methods for details) describing the number of shared species between seaboards of the softbottom subset (EC: English Channel; BB: Bay of Biscay; MS: Mediterranean Sea). 

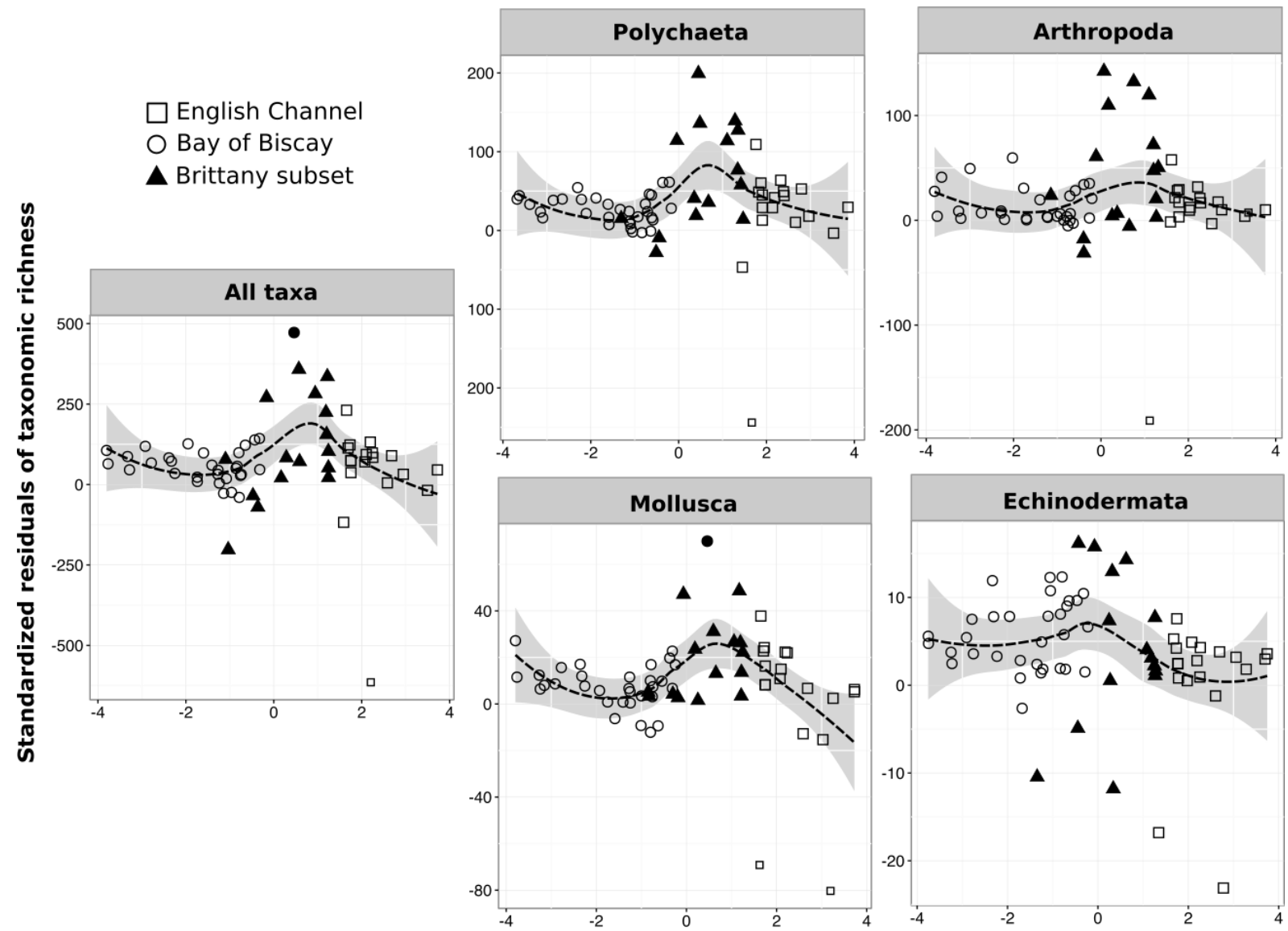

Standardized residuals of latitude

Fig. 4: LOESS regressions between species richness and latitudinal bins of the soft-bottom subset while controlling for sampling effort from the Northern English Channel to the Southern Bay of Biscay. Solid lines represent LOESS regressions and gray shades confidence intervals. 